\title{
Emotional Transition in Social Movements. The PAH Case
}

\author{
Ferran Giménez Azagra \\ UNIVERSITAT DE BARCELONA (UB) \\ ferran21_2001_yahoo.com \\ ORCID: 0000-0002-1163-0986
}

Received: 25/06/2018

Accepted: 07/01/2019

\begin{abstract}
We find that some fractured societies, in grappling with Neo-Liberalism as a political project, embark on an emotional transition to win hearts and minds for new, fairer policies to tackle inequalities.

Thus, there are 'affective spaces' facilitating this emotional transition, thereby allowing the building of collective action. For these spaces to work well, they must be configured as chains of interaction rituals, which use emotional transformation to drive social change.

This paper is based on a documental analysis and an ethnographic study carried out between 2013 and 2018 in several assemblies of and actions taken by the PAH (a platform for those affected by home foreclosure) in several Catalan municipalities. It was conducted by participatory observation, focus groups and in-depth interviews with activists.
\end{abstract}

Keywords: ritual of interaction, collective action, emotions, emotional transition.

Corresponding author: Ferran Giménez Azagra. Departament de Didàctica i Organizació Educativa. Campus Mundet. Edifici Llevant, 2a planta. Passeig de la Vall d'Hebron, 171. 08035 Barcelona. Universitat de Barcelona. Barcelona (Spain).

Suggested citation: Giménez Azagra, F. (2019). Emotional Transition in Social Movements. The PAH Case. Debats. Journal on Culture, Power and Society, 4, 89-100. DOI: http://doi.org/10.28939/iam.debats-en.2019-7

\section{INTRODUCTION}

Interest in emotions has grown and broadened to the point where the 'Sociology of The Emotions' is now a discipline in its own right. Applying this new discipline to social movements has rendered notions of irrationality or an artificial separation between emotions and reason (whether instrumental or instinctive) obsolete as drivers of collective action. In this respect, Jasper (1997) opened a new path in noting that cognition, morale and emotions are inseparable from an analytical standpoint.

Even so, models seeking to explain how social movements harness emotions to foster collective action still lack a suitable theoretical-methodological base. That is why this paper tries to chart how the emotional transition linked to affective areas takes place through interaction rituals, which constitute the basis for mobilisation. However, before embarking on empirical and theoretical reflection, one first needs to accept a set of premises.

First, one needs to define social precariousness as structural dispossession stemming from dodgy, unpredictable living and employment conditions that above all reflect imperatives covering "flexibility, availability, multilocation and mobility in both temporal and spatial terms" (Ricceri, 2011: 68). This objective reality has to 
be placed against the background of Neo-Liberal power, which takes the form of a subjective, political project (Lazzarato, 2006). This domination is masked behind formulas of individual responsibility, moral obligation, and individuals' acquiescence in their dispossession. This boils down to exploiting emotions in the management of inequalities, which in the final analysis are simply forms of social control (Lazzarato, 2006).

Second, one needs to assume the concept of a dual subject - that is to say of a reflective subject and of a social actor who combines the decisions and autonomous actions and criticisms of others configured through the special features of each social interaction and in keeping with certain norms, codes, group/social values.

Third, stemming from the second point, one has to accept that the answer to such domination-based affectivity is also a political task that develops in parallel with the creation of an alternative affectiveness. This political, protest-based political praxis requires the emergence and management of emotions that are experienced within the social movement to achieve both cognitive and affective liberation.

\section{RITUAL INTERACTION CHAINS AS A MODEL OF EMOTIONAL TRANSITION}

Collins' (2009) theoretical proposal is one of a situational Sociology in which ritual is conceptualised as a "mechanism for focusing both emotion and attention, creating a temporarily shared reality" (Collins, 2009: 21). This is a temporal unit, a meeting between "human bodies charged with emotion and awareness by virtue of chains of previous gatherings" (Collins, 2009: 18). The subjects or actors thus pass through a social reality conceived as an emotional market in which there are various kinds of interaction depending on their emotional charge and, above all, a corporal process. The actor seeks rituals with the greatest emotional charge until he or she dominates every field, be it institutional or non-institutional.

Thus the characteristics of an Interaction Ritual (IR) are:
(1) the physical meeting of two or more persons such each actor influences the others, whether or not they happen to be aware of it; (2) the presence of barriers that make it clear who is taking part and who is not; (3) shared focus on the same object, making it possible to create a common awareness; (4) an emotional experience and mood shared by participants (Ibid.: 72).

Where the process works well (that is, where it does not fail or become 'forced', as happens in some cases), a kind of consonance emerges from shared attention and feelings, creating a collective emotional and cognitive experience. Collins precisely describes the effects of the interaction ritual: (a) affiliation, social emotion; (b) individual emotion in the form of self-confidence, enthusiasm, and initiative for action; (c) the creation of symbols representing the group, whether they be words, gestures, or icons; (d) shared morality, in which it is one's duty to participate in the group, respect and defend its symbols, and in which undermining group solidarity is reprehensible (Ibid.: 73).

This ritual enshrines a motivational model in which bodies seek other bodies to share moments of collective effervescence in a continuous material-social flux oiled by emotional consonance - both corporal and cognitive-symbolic - that gives ritual its socially transformational role in interactions ranging from the micro-social level to the face-to-face one. Thus Collins (2009: 66) states: "An intense ritual experience creates new symbolic objects and energy driving greater social changes. IR is a mechanism for change.

At this juncture, it is worth asking what emotions are shared in these rituals and how the path to emotional transition (and thus social mobilisation) is paved.

\section{METHODOLOGICAL AND CONTEXTUAL NOTE}

The analysis in this paper is based on a socio-constructionalist perspective of emotions (McCarthy, 1994; Enciso and Lara, 2014), which argues that emotions exist because they are socially constructed. This configuration process occurs at three levels (Boiger and Mesquita, 
2012): (1) momentary interactions; (2) relational interactions; (3) the socio-cultural context (incorporating the first two), understood as a framework modelling and limiting meanings and thus what can be emotionally expressed (i.e. following the social norms governing emotions) (Kemper, 1981). In this respect, the situation (Miles and Huberman, 1984) is considered as the unit for analysing emotions expressed through practices, language, and social interaction. These situations are covered by assemblies and actions forming the repertoire of protest and are defined as an event (Dubet, 2010; Lazzarato, 2006) - that is, a moment opening up new collective forms of relationship and interpretation of the social setting, and as a reformulation of individual and collective priorities. Last, the data are analysed from a hermeneutic perspective based on grounded theory (Glaser and Strauss, 1967; Charmaz, 2006), as a form of "inductive approximation where immersion in the data yields the point of departure for a theory on the phenomenon" (Guillemette, 2006).

This study stems partly from field work carried out for a doctoral thesis between 2013 and 2015; however this work later stretched out to 2018. In total, fifteen indepth interviews were conducted of activists (eleven women, four men) drawn from five PAH assemblies (Barcelona, Girona, Badalona, Blanes, Sant Celoni) and a discussion group with four activists from $\mathrm{PAH}$ Baix Montseny (Barcelona) and PAH Blanes (Girona). As to participant observation, this was through direct involvement in various kinds of assembly (co-ordination, general, new cases, working parties, and local committees). In addition, there was participation in protests such as bank occupations, plastering bank branches with protest posters ${ }^{\mathbf{1}}$, marking empty flats, rallies, demonstrations, 'alternative' social fairs, celebrations, and informal gatherings. There were peaks and troughs in this participation between 2013 and 2018. The Ethnography was completed with a documentary analysis of the materials produced by the groups, such as manifestos, collective action manuals, social works, and press notes during this period.

1 In some cases, bank branches were 'invaded' and plastered with protest posters on the inside too.
PAH was chosen for study for two main reasons. The first was that it clearly incarnated individuals who had been or were about to be evicted from their homes. The second was the clear importance of emotions in the construction of their collective action - something that strongly emerged in the first part of the fieldwork (2013-2015). In this respect, it is worth saying that what spurred the writing of this paper were the results of the doctoral thesis and its discourse analysis (Conde, 2009), which revealed major translations between two semantic fields, each expressing a given discursive position. One of these discourses was based on the victim-member, the other on the activist-member. Among other things, these discourses were nurtured by agency of a strongly emotional nature (Giménez, 2017). This basis served to build the paper's hypothesis on emotional transition.

At this juncture, readers need to bear in mind the following information on $\mathrm{PAH}$, the social movement studied in this paper.

Plataforma d'Afectats per la Hipoteca (PAH) [Foreclosure Victims' Platform] is a movement that was set up in Barcelona in 2009, stemming from the $V$ de Vivenda ['H' for Housing] movement. PAH gradually spread its reach throughout Spain. The movement's aim was to defend the right to housing yet most of its actions focused on defending property - specifically that of people with mortgage arrears facing the prospect of foreclosure and eviction ${ }^{2}$. The movement's organisation steadily became more complex but each local assembly had a lot of freedom in deciding its strategies and actions for defending its members' right to housing. PAH produced a wide range of manuals (on drawing up actions and social initiatives; negotiating with banks; stopping the wave of foreclosures and evictions). This local autonomy fostered great democratisation given that each municipality or promoting group could set

2 Translator's note: Here it is worth noting the highly anomalous nature of Spain's mortgage system. A mortgagee who falls behind with payment not only faces repossession but is also is left with a lifelong debt (the outstanding mortgage). This, combined with irresponsible lending before the 2008 financia crash, sharp Spanish banking practices, and a property boom of surreal proportions foreshadowed a social disaster 
up an assembly based on collective learning without having to stick strictly to PAH's organisational structure whether at the regional level (in Spain, the so-called 'Autonomous Community' tier of government) or at the State level.

What kind of people sought PAH's help? Here one should distinguish between promoting groups and activists. The former were drawn from bodies usually representing marginalised groups - members or former members of political parties and/or trade unions. The activists were overwhelmingly women with limited education and political experience. Many of them were immigrants who were precariously employed and had not been previously politically socialised. While some men took part, it was largely women who led the movement, the committees, and who made the biggest effort.

\section{EMOTIONS INVOLVED IN THE TRANSITION}

Going beyond the classification of emotions presented by Goodwin and Jasper (Goodwin et al., 2004; Jasper, 2006a), we focus here on how these emotions are linked to political action, specifically with collective dispute. When it comes to emotions, these are neither an automatic knee-jerk response nor the product of awareness and great deliberation. Rather they are a form of information processing which may be faster than our brains can grasp (Leventhal and Tomarken, 1986). Thus, according to Nussbaum (2001: 23), "Emotions always imply the idea of an object together with its prominence or importance thus they always involve appreciation or evaluation". So emotions play a regulatory, stratifying function in the pursuit of certain ends, making them strategic elements in collective action. From this standpoint, Jasper (2006b) proposes five human goals: (1) reputation; (2) sensuality; (3) connection; (4) impact on the world; (5) curiosity. According to him, these five goals form part of and become visible in social movements. This paper focuses on the emotions associated with reputation and forging links, given their relevance in building mobilisation — something that emerged from our earlier fieldwork.
Reputation, defined as "a desire for due honour, pride and the recognition of one's own humanity" (Honneth, 1995), is developed through a moral battery ${ }^{3}$ powered by pride and shame. It is a response to the affective control processes implied by fear (Gould, 2001; 2003; 2009) and the threat this poses subjects' dignity. Here, pride and shame are two moral emotions given that they imply value-judgements on the object to which they are applied. Second, the link, understood as a feeling of belonging, of awareness that one is part of a group, is manifested through love and enthusiasm that in turn forge affective loyalties based on participation and on long-term collective action (Jasper, 1998; Polletta and Jasper, 2001; Flesher Fominaya, 2010). Last but not least, the impact is linked with expectations of action, which give hope and confidence and - linked to these emotions - confer the power of agency (Wood, 2003). Such expectations and emotions constitute the collective feeling that the group's actions will prove successful and that they will form the basis for future actions until their goals are reached. One should recall that emotions can be activated by opposing forces, which is simply a zero-sum game: enthusiasm/apathy, hope/desperation, trust/mistrust.

The emotional journey taken by the subject through his or her participation in the social movement can be seen as a four-stage temporal framework. Each individual trajectory stresses one of these stages in terms of intensity and duration, even though some individuals may not complete this transformation. Thus there is a first 'accumulation stage' stemming from a sense of injury and threat. The second stage involves joining the movement and of emotional bonding. The third stage involves emotional reparation. The fourth stage covers taking action in the context of a dispute.

3 Jasper (2012) used the term moral battery to define a category of two antagonistic emotions that might be likened to the anode and cathode in a battery, which power action once they have been connected. The most studied 'battery' has been pride-shame, based on studies of gay and lesbian movements. 


\section{STAGES IN THE EMOTIONAL TRANSITION}

\section{Accumulation}

This is the first stage and takes place outside a social movement. The individual finds himself or herself subject to the logic of Neo-Liberal domination, under the thrall of its subjectivity and of its affective control (stemming from precariousness and thus from social vulnerability) (Lazzarato, 2006; Giménez, 2018).

Mainstream PAH members are subject to foreclosure proceedings (that is to say, they face losing their homes because of mortgage default). These individuals feel threatened, ashamed, guilty, and isolated and in general, that they have failed in life (Giménez, 2017). As GD1D1 noted: "You see someone who is crestfallen, on the verge of tears, lost, and who is at their wit's end". The situation is felt as a stain upon one's honour, a direct threat, loss, and discrimination. The individual feels vulnerable and that all his or her expectations in life have been brought to naught, constituting a brutal negation of the subject's self-determination. The social precariousness of those who find themselves in such dire straits was noted earlier, as was the need to ensure social control through subjects' acquiescence to such inequities. Thus, we see a mobilisation cycle in which many of those on the lower social rungs band together to escape the dire straits they find themselves in. The grim prospect of dispossession is the catalyst for resistance and emancipation (Schierup and Bak Jørgensen, 2016). Thus, we find members of Sindillar (a house-cleaners' Trade Union), the Iaioflautes [a 'grannies' protest group sprung from the 15-M movement] l'associació de cambreres de pis [roomcleaners' association], Las Kellys [hotel-room cleaners association] and the Sindicat de Manters de Barcelona [Barcelona Street-Hawkers Trade Union], to give just a few examples of those with dodgy jobs. These groups also highlight the way the crisis has dashed expectations and sparked a shared perception of a grave threat to their well-being and dignity.

4 See the list of codes used for interviews and discussion groups
We are therefore speaking of people in tricky circumstances who have been deeply scarred by the Neo-Liberal project, and the inequitable treatment meted out by the economic and social system in both the welfare and wage spheres (Lazzarato, 2006). These people find themselves in a very weak position, in which the burden falls on the individual. This is in keeping with the logic of domination, which each individual internalises through the projection of negative emotions that keep them submissive and in the thrall of the powers that be.

When this point is reached, what is it that makes an individual paralysed by these emotions take the plunge and join a social movement? According to Dubet (2010), this leap is taken when the individual (and thus an ethic actor) feels at odds with the forces of domination hindering him or her from acting as a free agent. From the emotional standpoint, one can hypothesise the need for good standing (reputation) as a life goal - that is to say, that there is an inextricable link between blame and shame on the one hand and pride on the other, constituting a 'moral battery' (Jasper, 2012) as the main mechanism spurring participation in a social movement.

The second stage in the process begins once the individual has taken this important first step.

\section{Emotional reception}

The first contacts tend to be informal conversations with a member of the group, or even a chance meeting at a public event or during a protest (gathering, occupation, talk). When someone takes part in an assembly for the first time (whether as a situation or an event), the emotional welcoming process kicks in and takes clearer form. That is why an interaction ritual is played out, allowing transformation of initially negative, weakening emotions into other emotions that are more invigorating and that spur both individual and collective action - in other words, those that are needed to build the emotional agency needed to forge a strong movement. Yet why can we say that the ritual form begins in the assembly? 
The first reason - following Collins' (2009) criteria - is because the assembly is a physical meeting of people whose attention and communication focus on the same subject, namely the various forms taken by social vulnerability (foreclosure proceedings, eviction, precarious housing, long-term unemployment). These are intense experiences that touch on the key aspects of people's lives and thus trigger deep cognitive and emotional responses in those suffering such vulnerability. In the words of PAH1:

We think the welcome is very important because it's when people get the chance to unburden themselves and cast off their sense of guilt. Many people feel guilty that they took on debt. The important thing is to help them lift this weight of guilt off their shoulders and calm down. Some people are mired in despair so it's important to help them take a deep breath and see the strength of collective action, that a problem shared is a problem halved. We show them the problem lies in the system, not in them. We show them that guilt will get them nowhere and that the solution lies in collective action.

This approach forges greater empathy, an almost spontaneous feeling of a community of fellow-sufferers among all those attending the assemblies, drawing a symbolic line tracing the bounds of what lies inside the assembly and what beyond it.

All the individuals in an assembly clearly have a common awareness of the same cognitive-symbolic object. Yet the event also creates a shared emotional experience, which is key for firing the energy needed to change things. We therefore speak of the assembly as where ritual interaction takes place. It is a forum where people gather, and an event that manages and develops symbolic, cultural, cognitive, and emotional processes, shaping collective transformation founded on shared experience.

The second reason, as mentioned earlier, is that the transformational nature of ritual lies in its power to spark the emotional energy leading to collective euphoria, cathartic moments when corporal, material, and social moments meld to create a great upwelling of emotional consonance. The emotional and collective energy generated by this triple confluence (corporal, emotional, and cognitive-symbolic) is what gives the ritual its transformative power and role. Thus, entering an assembly is a moment for emotional unburdening in which the individual publicly confronts his/ her sense of shame, the scars inflicted by Neo-Liberal subjection, and the threat posed to his/her good standing. In welcoming assemblies, new members rise from their seats, grab the microphone, and pour out their woes. They give emotional discourses, not political or strategic ones. They talk about the threats made by the bank following mortgage default, how their children may be taken into care, of the helplessness they feel after years of unemployment or of living in sub-standard housing ${ }^{5}$. These emotions are understood and shared by everyone else in the assembly. It is a moment of collective recognition of 'us and them', of comrades 'in the same boat' but also of other disadvantaged groups (for example, hotel and house cleaners). Someone then bursts into tears, their voice breaking with emotion and shame. A few moments go by and then the group applauds, encouraging the speaker to go on: "Courage Ángeles! You can do it! You are not alone". Some members get up and hug the speaker, encouraging him or her to finish". As noted by interviewee PAH2, "The value of the assembly is the sense of empowerment - it's a bit like Alcoholics Anonymous, right?"

This initial group interaction sublimates the materialism of bodies, objects and space and their expressions and dispositions, turning all these elements into a continuum of shared emotional energy, and - as noted earlier - of emotional consonance. The empathy, the emotional unburdening open up a path in which shame, guilt, isolation, fear, the stain on one's honour and worth give way to their emotional opposites.

5 These comments are taken from various witnesses who were observed in PAH Gironès and PAH Badalona assemblies in 2014. 


\section{Emotional Reparation}

This involves recovering one's damaged reputation, following Honneth's concept (1995). This emotional reparation is made by steadily forging and strengthening a link between awareness of belonging to the group and boosting participation in the movement. This feeling of belonging to certain kinds and forms of collective identities represents "a basic human need for loving emotions (Berezin, 2001), pride (Scheff, 1994), and enthusiasm (Collins, 2009)". Its importance lies in the fact that such identities and sense of belonging forge affective commitments and loyalties between the individual and the group (Jasper, 1998; Polletta and Jasper, 2001), making it easier for each individual to take on collective practices, goals, and values. It is an incorporation of the 'collective self' filtered by each subject's reflections, allowing for varying degrees of adherence to the central elements of collective identity. This gives rise to mutually compatible but varying individual interpretations of that identity.

The link, belonging, collective identity, and a whole set of accompanying cultural, moral, emotional, and symbolic contents are assimilated and re-interpreted by individuals through immersion in activists' gatherings and events. These are community spaces and interaction structures (Tejerina, 2010) making up stable relational networks that forge trust and give mutual support. The movement's daily routine comprises attending assemblies, advisory committees, tendering help in negotiations, squats, performances, training workshops, celebrations of successes, making placards, talks, and anniversary dinners. The result is the construction of a space for the movement in which different interaction scenarios play out through rituals of varying emotional intensity and that more or less standardise the use made of symbolic instruments. This continuum allows a recent recruit to assimilate the elements involved in the ritual, their distribution, their hoped-for impact, and their purpose. Each expressive-symbolic formula, whether it be silence, a stirring slogan, a hug-in, or an aesthetic feature (Tshirts, disguise, placard) has its place, moment, and function in the ritual, and each ritual has its own collectively constructed rules.
This process of forming affective loyalties also appears in moral emotions (Traïni, 2009), which consist of approval or disapproval of given attitudes and behaviour patterns in the group. Thus, defending group purposes, values, and symbols is 'right' whereas acting on behalf of other, selfish interests is 'wrong' and runs counter to the group's moral code. As Activist PAH3 put it, "In my view, they come along and when their problem is solved, it's 'Thanks and I'm off'. In my book, that's just not right". This moral projection of community-nurtured affectiveness and emotions is also one of the impacts of the interaction ritual.

[I say that the PAH has the power to turn a victim into an activist and that is wonderful. Speaking for myself, I was in a terrible state when I joined the assemblies - I was knocked for six. But after a few days, I was in fine fettle and ready to do battle] (Interview with PAH4).

Then several weeks or even months go by since that first assembly. The shame, blame, and loss of dignity borne by that individual fade as he or she takes part in the interaction rituals more or less often, and with greater or less intensity, gradually leading to active participation in the movement. The subject acquires an emotional repertoire that mixes love, pride, enthusiasm, affective and moral loyalty towards the group, giving him/her what it takes to join in the political battle.

\section{Activation for battle}

The last stage of activation is both political and deliberative, such that the object on which emotions are projected undergoes a complete transformation. Hitherto, in taking part in the movement, the subject's emotions stemmed from the thwarting of his/her expectations in life. As noted earlier, such expectations/goals are generally those imbued by the powers that be and include such things as: looking after one's family; earning a decent wage; owning one's own house; having a good standard of living. At the same time, the ritual of cognitive and emotional transformation has advanced to the point where there are basically two objects of the individual's emotions. The first is the group, whose 
members have taken part in the subject's emotional healing through the projection of trust, joy, pride (in belonging) and affective loyalty. The second is one of agency, which involves turning the threat to one's reputation, pride, and dignity into a weapon with which to fight. Hence, initiative, hope, and enthusiasm accompany these discursive, symbolic, strategic, and organisational strategies for countering threats.

These dominant emotions include indignation and are linked to a desire to make an impact and produce change. The wish to make an impact (Jasper, 2012); to "change the world" is one of the main incentives for the movement's political action. However, one of the impacts of the ritual is of a pragmatic, contingent nature. A fellow member's lack of social security coverage, his/her health problems, unpaid wages, or homelessness are all issues that the group takes to heart and for which it collectively seeks solutions. Thus practices in the rituals and in discourses include criteria covering effectiveness and efficiency. The verbs used to express indignation and initiative include 'discussing', 'evaluating', 'fighting', 'attaining', 'organising', and 'solving'. This does not mean that hugs, weeping, applause, and in general cathartic moments disappear but rather that the agency discourse also embraces strategic, pragmatic considerations in taking the struggle further.

[You have to come and empower yourself, fight for your house, fight for your rights, you have to defend your home. If you do not defend your home, I cannot do it for you because I do not know what you want to do with your home...] (Interview with PAH5).

In fact, when PAH carries out a 'social action' (that is, occupation of a block of flats so that it can house members of the group), it employs a liberation ritual that includes welcoming the re-housed families, festooning the building with materials proclaiming the movement, holding both 'welcome' and protest meetings; exhibiting symbols; community singing. All these elements act as props to set the scene for collective euphoria and emotional consonance.
In the initial stages, the stimulus provided by a ritual (capable of generating collective emotional energy) focuses on the need to welcome newcomers and to heal an individual who feels ashamed and threatened, and so needs rescuing. According to one of those interviewed:

[Someone who was weeping today or two weeks ago and was suicidal or whatever, will be laughing two weeks hence, doing things, and helping others who maybe found themselves in the same boat] (Interview with PAH2).

The small victories won by the movement also play a part - for example a 'social action' or stopping an eviction. As Activist PAH6 noted, "Nothing gives people a stronger will to keep fighting than does a victory, and PAH has won many small battles". These victories provide a measure of the movement's impact and justify PAH's practices and aims given that they make the interaction ritual both more plausible and measurable in terms of outcomes.

Thus the strategic value of actions is subsumed in their ability to foster emotional consonance and a sense of belonging that ensures the updating, ratification, and continuance of a movement's interaction rituals in all their forms.

Last, one should reflect on the final stage of the emotional transition, which is the disappearance of the emotions driving collective action. The fact that it was not possible to interview those who no longer take part in the movement limits interpretation of the phenomenon. One also needs to bear in mind that the process of emotional exhaustion and of abandoning activism do not necessarily stem from a loss of the ritual's effectiveness. Rather, as we have tried to show here, there are other factors at work that lie beyond our analysis.

\section{CONCLUSIONS}

First of all, one must draw attention to the leading part played by women in the processes of emotional 
and political transformation described in this paper. From a socio-demographic perspective, one can hypothesise that the low educational, social, and political 'capital' of the movement's members typifies patriarchal (traditional) socialisation patterns in which home ownership, motherhood, and marriage are the hallmarks of adult life. From this, one can argue that there is a transfer of child-rearing and care tasks from home to the movement's social and political sphere. As Hochschild states, the lack of other means "forces women to create resources based on feelings" (Hochschild, 1983: 163) — something that is in part possible because of the emotion management skills girls acquire during their childhood socialisation (Jasper, 2012). Yet this hypothesis needs nuancing. What is really relevant is women's ability to convert emotional capital into political capital and activism, such that caring tasks, emotional healing, providing support, and listening to others are taken on and practiced by the whole group, regardless of gender differences. Thus women emerge as promoters of emancipatory change. From this standpoint, gender socialisation is a major factor explaining how social movements use affectiveness and emotions as resources for collective action, projecting political meaning, and for collective responsibility in caring for others.

Second, some studies on the relationship between emotions and the construction of collective action assume that feelings - such as indignation, pride, or a sense of injustice - drive action from the outset. Without under-estimating the importance of such feelings in catalysing collective action, the emotional transition model suggests that the start of the individual's path in a movement needs to be sought in the individual's preceding emotional state. This is the one found when the subject enters the movement and is defined by the 'welcome' ritual. This state is defined and explained by the previous 'accumulation' stage. Thus, as we have said, the emotions beginning the process are shame, guilt, and threats to the subject's dignity.
In addition, assuming that collective emotional energy underlies the transformational process, one should reject the notion of an 'emotional market' mooted by Collins (2009). Here, it is not so much a question of offering diverse rituals of varying intensity but rather of ensuring the right ritual elements are present at a given event, for example in an assembly. Put another way, while one can accept that emotional energy is the product of subjects' own practices in an interaction setting, these people are not energy consumers but rather energy producers. This change in the actor's role allows one to say that there are symbolic and emotional incentives fostering ongoing participation in this ritual. In this respect, the continuance of the event and the emotional conditions for interaction make the aforesaid transition possible. Emotions projected on the link and impact (enthusiasm, affective loyalty, hope, initiative) constitute the main axes of emotional consonance.

One should also note that while the ritual provides scope for the creation of new symbols differing from or opposing those of the powers that be, the model does not establish what constraints act on the configuration of the ritual itself. By the same token, specification is lacking when it comes to the kinds of emotions and their distribution in the ritual - a shortcoming that this paper has sought to mitigate. Yet one has to admit both the value of Collins' (2009) model for determining the elements required by an interaction ritual from a social constructionist and symbolic interactionist perspective, and the model put forward in this paper.

Finally, one should state that Situational Sociology needs to be applied if we are to gain a better understanding of the impact and social changes that social movements are capable of. In taking such an approach, the analysis should cover both the symbolic conditions under which the interaction takes place and the inner life of social movements, paying special attention to the transformational potential of emotions. 


\section{BIBLIOGRAPHIC REFERENCES}

Berezin, M. (2001). Emotions and political identity: mobilizing affection for the polity. In J. Goodwin, J. M. Jasper and F. Poletta (eds.), Passionate Politics (pp. 83-98). Chicago: University of Chicago Press.

Boiger, M. and Mesquita, B. (2012). The construction of emotions in interactions, relationships and cultures. Journal Emotion Review, 4(3), 222-229.

Charmaz, K. (2006). Constructing grounded theory. London: Sage.

Collins, R. (2009). Cadenas de rituales de interacción. Barcelona: Anthropos.

Conde, F. (2009). Análisis sociológico del sistema de discursos. Madrid: CIS.

Dubet, F. (2010). Sociología de la experiencia. Madrid: CIS.

Enciso, G. and Lara, A. (2014). Emociones y ciencias sociales en el siglo xx: la precuela del giro afectivo. Athenea Digital, 14(1), 263-288.

Flesher Fominaya, C. (2010). Creating cohesion from diversity: the challenge of collective identity formation inthe global justice movement. Sociological Inquiry, 80, 377-404.

Glaser, B. and Strauss, A. (1967). The discovery of grounded theory. Chicago: Aldine Press.

Giménez, F. (2017). Movimientos sociales y construcción de subjetividades. Los casos de la PAH y de la CUP, tesis doctoral, Universidad del País Vasco.

Giménez, F. (2018). Desinstitucionalización de lo social y constitución del sujeto. El camino hacia la emancipación colectiva. En S. Martí, R. González, R. Gomà y P. Ibarra (eds.), Movimientos sociales y derecho a la ciudad. Creadoras de democracia radical (pp. 261-274). Barcelona: Icària.

Goodwin, J., Jasper, J. M. and Poletta, F. (2004). Emotional dimensions of social movements. En D. A. Snow, S. A. Soule y H. Kriesi (eds.), The Blackwell Companion to Social Movements (pp. 413-432). Malden: Blackwell.

Gould, D. B. (2001). Rock the boat, don't rock the boat, baby: ambivalence and the emergence of militant AIDS activism. En J. Goodwin, J. M. Jasper y F. Poletta (eds.), Passionate Politics (pp. 135-157). Chicago: University of Chicago Press.

Gould, D. B. (2003). Passionate political processes: bringing emotions back into the study of s o c i a 1 movements. En J. Goodwin y J. M. Jasper (eds.), Rethinking Social Movements (pp. 282-302). Lanham: Rowman \& Littlefield.

Gould, D. B. (2009). Moving Politics. Chicago: University of Chicago.

Guillemette, F. (2006). L'approche de la Grounded Theory; pour innover? Recherches qualitatives, 26(1), 32-50.

Hochschild, A. R. (1983). The Managed Heart: Commercialization of Human Feeling. Berkeley: University of California Press.

Honneth, A. (1995). The Struggle for Recognition. Cambridge: MIT Press.

Jasper, J. M. (1997). The Art of Moral Protest: Culture, Biography, and Creativity in Social Movements. Chicago: University of Chicago Press.

Jasper, J. M. (1998). The emotions of protest: affective and reactive emotions in and around social movements. Sociological Forum, 13, 397-424.

Jasper, J. M. (2006a). Emotion and motivation. En Goodin, R. and Tilly, C. (eds.), Oxford Handbook of Contextual Political Studies (pp. 157-171). Oxford: Oxford University Press.

Jasper, J. M. (2006b). Getting Your Way. Chicago: University of Chicago Press.

Jasper, J. M. (2012). Las emociones y los movimientos sociales: veinte años de teoría e investigación. Revista Latinoamericana de Estudios sobre Cuerpos, Emociones y Sociedad, 10, 48-68.

Kemper, T. (1981). Social Constructionist and Positivist Approaches to the Sociology of Emotions. American Journal of Sociology, 87(2), 336-362.

Lazzarato, M. (2006). Políticas del acontecimiento. Buenos Aires: Tinta Limón.

Leventhal, H. and Tomarken, A. J. (1986). Emotion: today's problems. Annual Review of Psychology, 37, 565-610.

McCarthy, E. D. (1994). The Social Construction of Emotion, new direction for culture theory. Journal Social Perspectives of Emotions, 2, 267-279.

Miles, M. and Huberman, M. (1984). Qualitative data analysis. A sourcebook of new methods. London: Sage Publications. 
Nussbaum, M. C. (2001). Upheavals of Thought. New York: Cambridge University Press.

Polletta, F. and Jasper, J. M. (2001). Collective identity and social movements. Annual Review of Psychology, 27, 283-305.

Ricceri, M. (2011). Europe and social precarity - Proactive elements for system interventions. En A. P. Hermann and S. Kalaycioglu (eds.), Precarity. More than a Challenge of Social Security. Or: Cynicism of EU's Concept of Economic Freedom. Bremen: Europäischer Hochschulverlag.

Scheff, T. J. (1994). Bloody Revenge: Emotions, Nationalism, and War. Boulder: Westview.

Schierup, C. U. and Bak Jørgensen M. (eds.) (2016). Politics of Precarity: Migrant conditions, struggles and experiences. Leiden \& Boston: Brill Academic Publishers.

Tejerina, B. (2010). La sociedad imaginada. Movimientos sociales y cambio cultural en España. Madrid: Trotta. Traïni, C. (ed.) (2009). Emotions... Mobilisation! Paris: Sciences Po.

Wood, E. J. (2003). Insurgent Collective Action and Civil War in El Salvador. New York: Cambridge University Press.

INTERVIEW CODES ADN DISCUSSION GROUP

\section{Discussion Group 1:}

GD1D1: Woman, mortgage victim and activist*, 50-55 years old, without a previous experience of activism, promotor of PAH Baix Montseny (Barcelona).

\section{Interviews:}

PAH1: Woman, mortgage victim and activist, 35-40 years old, member of the local PAH assembly in Sant Celoni (Barcelona Province), without previous experience of activism.

PAH2: Woman, mortgage victim and activist, 35-40 years old, promotor of the local PAH assembly in Badalona, previous membership of PSUC (Partit Socialista Unificat de Catalunya [Catalan Socialist Party) and neighbourhood associations.

PAH3: Woman, activist (without mortgage problems), 45-50 years old, promoter of the local PAH assembly in Badalona, previous membership of PSUC and ICV (Iniciativa per Catalunya-Verds).

PAH4: Woman, activist (without mortgage problems), 55-60 years old, promotor of the PAH Gironès assembly (Girona), previous membership of CCOO (Comissions Obreres, a major Trade Union).

PAH5: Woman, mortgage victim and activist, 55-60 years old, member of the PAH Gironès assembly, without previous experience of activism

PAH6: Woman, mortgage victim and activist, 50-55 years old, without previous experience of activism, member of PAH Baix Montseny (Barcelona).

* Affected by foreclosure proceedings. 


\section{BIOGRAPHICAL NOTE}

Ferran Giménez Azagra was awarded a PhD in Sociology from Euskal Herriko Unibertsitatea (UPV-EHU) [University of The Basque Country]. He is currently a Secondary School Teacher at l'Institut Ribot i Serra, Sabadell, specialising in Social-Community Intervention. Giménez is also an Associate Professor at Universitat de Barcelona (UB) in the Department of Teaching and Educational Orientation. His main current lines of research are social construction processes in social movements: collective identities, collective action frameworks, subjectivities and emotions. 